\title{
MAX-Interacting Protein 1
}

National Cancer Institute

\section{Source}

National Cancer Institute. MAX-Interacting Protein 1. NCI Thesaurus. Code C28556.

Max-interacting protein 1 (228 aa, $\sim 26 \mathrm{kDa}$ ) is encoded by the human MXI1 gene. This protein plays a role in transcription factor binding and transcriptional repression. 